\title{
SOEP
}

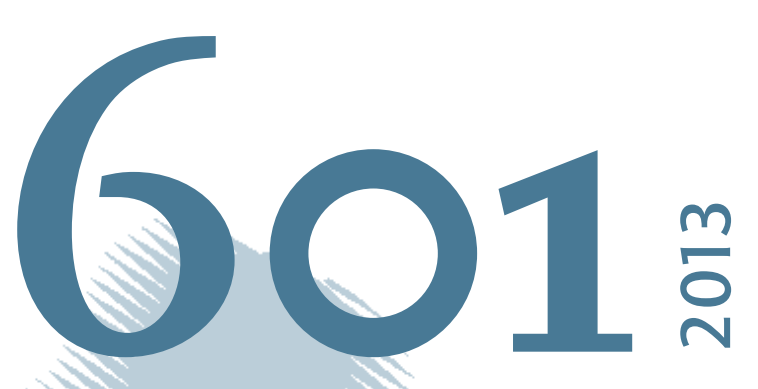

SOEPpapers

on Multidisciplinary Panel Data Research

\section{Life satisfaction and unemployment - the role of voluntariness and job prospects}

André Hajek 


\section{SOEPpapers on Multidisciplinary Panel Data Research}

at DIW Berlin

This series presents research findings based either directly on data from the German SocioEconomic Panel Study (SOEP) or using SOEP data as part of an internationally comparable data set (e.g. CNEF, ECHP, LIS, LWS, CHER/PACO). SOEP is a truly multidisciplinary household panel study covering a wide range of social and behavioral sciences: economics, sociology, psychology, survey methodology, econometrics and applied statistics, educational science, political science, public health, behavioral genetics, demography, geography, and sport science.

The decision to publish a submission in SOEPpapers is made by a board of editors chosen by the DIW Berlin to represent the wide range of disciplines covered by SOEP. There is no external referee process and papers are either accepted or rejected without revision. Papers appear in this series as works in progress and may also appear elsewhere. They often represent preliminary studies and are circulated to encourage discussion. Citation of such a paper should account for its provisional character. A revised version may be requested from the author directly.

Any opinions expressed in this series are those of the author(s) and not those of DIW Berlin. Research disseminated by DIW Berlin may include views on public policy issues, but the institute itself takes no institutional policy positions.

The SOEPpapers are available at

http://www.diw.de/soeppapers

\section{Editors:}

Jürgen Schupp (Sociology)

Gert G. Wagner (Social Sciences, Vice Dean DIW Graduate Center)

Conchita D'Ambrosio (Public Economics)

Denis Gerstorf (Psychology, DIW Research Director)

Elke Holst (Gender Studies, DIW Research Director)

Frauke Kreuter (Survey Methodology, DIW Research Professor)

Martin Kroh (Political Science and Survey Methodology)

Frieder R. Lang (Psychology, DIW Research Professor)

Henning Lohmann (Sociology, DIW Research Professor)

Jörg-Peter Schräpler (Survey Methodology, DIW Research Professor)

Thomas Siedler (Empirical Economics)

C. Katharina Spieß (Empirical Economics and Educational Science)

ISSN: 1864-6689 (online)

German Socio-Economic Panel Study (SOEP)

DIW Berlin

Mohrenstrasse 58

10117 Berlin, Germany

Contact: Uta Rahmann | soeppapers@diw.de 


\title{
Life satisfaction and unemployment - the role of voluntariness and job prospects
}

\author{
André Hajek ${ }^{1}$
}

Lüneburg

October 2013

\footnotetext{
${ }^{1}$ This publication is a modified extract of my dissertation "Der Einfluss von Armut und Reichtum auf die Lebenszufriedenheit. Eine empirische Analyse mit dem SOEP unter besonderer Berücksichtigung des Capability Approach" ("The Influence of Poverty and Wealth on Satisfaction of Life. An empirical analysis with SOEP data, paying particular attention to Capability Approach") published by Herbert Utz.
}

E-Mail: andrehajek@alice-dsl.net

I would like to sincerely and gratefully thank my supervisor - Prof. Dr. Hans-Rüdiger Pfister - for his guidance and support during my dissertation. His continuous encouragement and insightful comments helped a lot. 


\title{
Life satisfaction and unemployment - the role of voluntariness and job prospects
}

\author{
André Hajek
}

Abstract

By using longitudinal data the relation between satisfaction with life and unemployment is analyzed in this study. Data used in this publication were made available by the German Socio Economic Panel Study (SOEP) at the German Institute for Economic Research (DIW Berlin), Berlin. A period from 1998-2009 is evaluated. This publication has two goals. (1) To estimate the effects of voluntary and involuntary unemployment on life satisfaction. (2) Moreover, the intent is to answer the question of whether job prospects influence life satisfaction. This study has yielded the following results: In contrast to voluntary job leavings involuntary job leavings noticeable reduce satisfaction. Furthermore, a lack of job prospects before leaving the last position decreases life satisfaction as well. Additionally, an exogenous stimulus (plant shutdown) diminishes satisfaction, especially those of men. The implications are discussed.

JEL: J64, I31

Keywords: life satisfaction, unemployment, SOEP, fixed-effects, job prospects, voluntariness.

\section{Zusammenfassung}

In dieser Arbeit wird die Beziehung zwischen Lebenszufriedenheit und Arbeitslosigkeit im Längsschnitt untersucht. Die Daten dieser Publikation beruhen auf Zahlen des Sozio-oekonomischen Panels (SOEP) am Deutschen Institut für Wirtschaftsforschung (DIW Berlin), Berlin. Es wird ein Zeitraum von 1998-2009 betrachtet. Der Fokus liegt dabei auf der Rolle der Freiwilligkeit und der beruflichen Perspektive für den Einfluss der Arbeitslosigkeit auf die Zufriedenheit. Zentrale Ergebnisse der Fixed-Effects-Regressionen: Im Gegensatz zu freiwilligen Ausschieden aus dem Beruf führen unfreiwillige Abgänge aus der beruflichen Tätigkeit zu einer starken Minderung der Zufriedenheit. Außerdem wirken fehlende berufliche Perspektiven nach der Beendigung einer beruflichen Tätigkeit in den geschätzten Modellen negativ auf die Zufriedenheit. Ferner führt eine Betriebsschließung, ein höchstwahrscheinlich exogenes Ereignis, zu einer signifikanten und bedeutsamen Minderung der Lebenszufriedenheit. Dies gilt in erster Linie für Männer. Die Implikationen werden diskutiert.

JEL: J64, I31

Schlagwörter: Lebenszufriedenheit, Arbeitslosigkeit, SOEP, Fixed-Effects-Regressionen, berufliche Perspektiven, Freiwilligkeit. 


\section{Content}

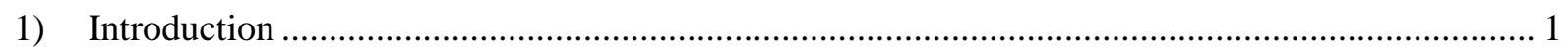

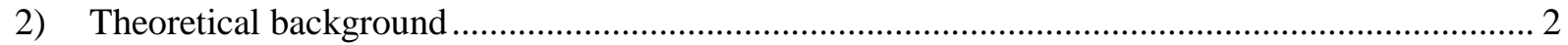

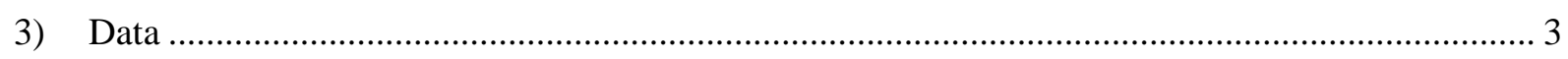

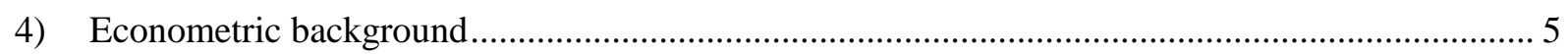

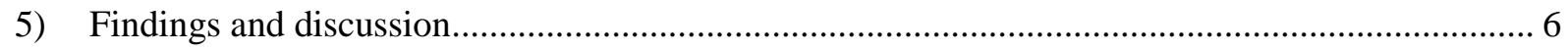

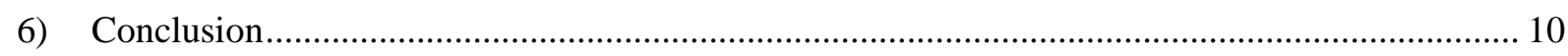

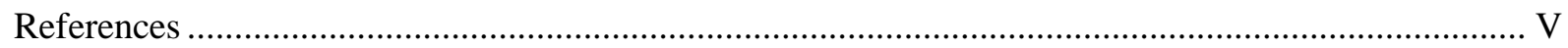




\section{Contents of Tables}

Table 1: Descriptive Statistics of dependent variable and control variables $(\mathrm{n}=248.627)$..................... 5

Table 2: Number of cases: voluntariness and job prospects................................................................. 5

Table 3: Overview about the effects: role of voluntariness and job prospects (SOEP-data, 1998-2009, unweighted) 


\section{1) Introduction}

In recent years, there has been a great deal of interest in subjective well-being. Causes were the imperfections of economic indicators (like gross domestic product) in measuring individual well-being. Consequently, these economic indicators could be put into question in industrial countries (e. g. Diener \& Seligman, 2004). That led to an intensified consideration of well-being measures, e. g. Stiglitz-Commission or the so called Gross National Happiness, which is anchored in the Bhutanese Constitution.

It is important at the outset to be explicit about what is meant by subjective well-being or life satisfaction. Subjective well-being is a multidimensional construct. Four separable components of subjective well-being have been identified in the past (for an overview: Diener, Suh, Lucas \& Smith, 1999): pleasant and unpleasant affects, domain satisfaction and life satisfaction. Satisfaction with life primarily refers to the cognitive evaluation of one's life (Pavot \& Diener, 2008).

In fact, the evaluation of life satisfaction enables individuals to use their own criteria to judge their life. Thus, it is often seen as a very appropriate measure to quantify well-being of individuals (Sumner, 1996, p. 151-155). Therefore, this publication uses this measure.

In the last years, researchers examined the relation between life satisfaction and dozens of predictors. For several reasons, a number of economists analyzed the relation of life satisfaction and unemployment. Scientists investigated, for instance, the role of repeated unemployment (Luhmann \& Eid, 2009) or the effect of long term unemployment (e. g. Clark \& Georgellis, 2012) on life satisfaction in developing and developed countries. Especially the non-pecuniary effect - for example, impaired self-respect - of unemployment on measures of subjective well-being was studied extensively (Winkelmann \& Winkelmann, 1995). Because of these drastic effects on life satisfaction, unemployment can be seen as involuntary. Thus, this relation has a lot of political implications, which will be discussed later.

Most of the recent findings have to deal with some limitations. Even if estimators of panel data econometrics are used, one cannot be sure about the causality in this relation. The possibility that unhappy workers voluntarily leave their job cannot be ruled out. As a result, it is essential to separate between voluntary and involuntary unemployment (Kassenböhmer \& Haisken-DeNew, 2009).

The contribution of this study to the existing literature is the following: Following Kassenböhmer and Haisken-DeNew (2009), this paper uses their separation and expands it to the job prospects (more details will be given in chapter 2). The questions are:

- Which role plays the voluntariness of unemployment in the effect on life satisfaction?

- What impacts on life satisfaction have job prospects after leaving the job on life satisfaction? 
All the SOEP waves from O to $\mathrm{Z}$ were used, covering the years 1998-2009. Based on this data, a separation between (a) the voluntariness of unemployment and (b) job prospects after the job leaving is possible.

The paper begins by clarifying the theoretical background (chapter 2). The third chapter goes on to describe the database. Chapter 4 sketches the estimation methods. The results are presented and discussed in the fifth chapter. Chapter six recaps the results. Furthermore, the connection to the capability approach is outlined.

\section{2) Theoretical background}

The next passage deals with the neoclassical theory of labor supply. Premises are:

- Unemployment is a result of free choice.

- Individuals maximize their utilities by choosing - at a given wage rate - a combination of employment (income) and leisure.

- The relation between income and leisure is substitutive.

As a consequence, unemployment is a product of poor attractiveness of work compared to the appeal of leisure. Hence, unemployed individuals would maximize their utilities. In this case life satisfaction of an individual, who is leaving his/her job, should be constant - under the condition of controlling for income discrepancies and other major variables (e. g. marriage).

What needs to be considered is that this theoretical approach is not compatible with a lot of research in the past. For example, on the basis of the conditional fixed-effects logistic regression (CLFE) ${ }^{2}$ Winkelmann and Winkelmann (1998) showed with SOEP-data from 1984-1989 (men, 20-64 years old): Unemployment reduces the life satisfaction drastically, even after controlling the monetary effects that go along with unemployment. Hence, the voluntariness of unemployment should be doubted gravely.

Kassenböhmer and Haisken-DeNew (2009) analyzed the connection between these two variables from another point of view. For this purpose, they used SOEP-data from 1991-2006. By using the background of job termination, they differentiated between voluntary and involuntary unemployment. The authors demonstrated that company closings have significant negative effects for women in the year of closing. They understand large investments in firm-specific human capital as one explanatory factor. With few exceptions: The reason for being unemployed has no more negative effects on life satisfaction for men. To conclude, it is urgently required to separate between voluntary and involuntary unemployment.

\footnotetext{
${ }^{2}$ Winkelmann and Winkelmann (1998) recoded life-satisfaction in a binary variable: satisfaction values $>7$ (overall mean) are coded as "1", otherwise "0". The ordinality of life satisfaction is maintained and with Chamberlains conditional logit-Schätzer (Chamberlain, 1980) they could control for unobserved heterogeneity.
} 
This publication extends that previous work by Kassenböhmer and Haisken-DeNew (2009). Thus, the job prospects are used in this work. Finally, this information is helpful to get more insights into the job leavings. It is argued that a combination of a dismissal and missing options dramatically decreases life satisfaction of men due to the rapid loss of self-esteem and other psychosocial consequences. In contrast, the mixture of resignation of employees and a new contract should increase satisfaction for some reasons: The old job with its possible low job satisfaction is in the past and the new contract ensures financial independence, higher job satisfaction ${ }^{3}$, and preserves self-confidence plus freedom of choice. To sum up, from a theoretical point of view, it is required to take job prospects into account when job leavings are investigated.

\section{3) Data}

The SOEP is a representative annually longitudinal study of private households, which is located at the German Institute for Economic Research (DIW Berlin). It started in 1984. About 20.000 persons and nearly 11.000 households participate every year. For instance, major topics are measures of subjective well-being, occupational biographies, income, health and employment (for further details: Wagner, Frick \& Schupp, 2007).

In SOEP dataset the questions of job leavings are addressed. For example, in the dataset from the year 1999:

Have you left a job since the beginning of 1998 (one which you also had before this date)? ["Yes"; "No"].

Additionally, the backgrounds of the job leavings were examined. Therefore, the voluntariness of job leavings can probably be depicted very well. People, who left their job, were asked in SOEP dataset:

How was this job terminated?

This article uses SOEP-data from 1998-2009. This period was primarily chosen for reasons of data availability. In these years the following answer options remain: office/work is closed; my resignation; dismissal; mutual agreement; temporary job or apprenticeship had been completed; reaching retirement age/ pension; suspension; purpose of self-employment/business; I took advantage of an early retirement plan; transfer within the company by own wishes; transfer by company to another position; other.

The empirical strategy is divided into four sections. First, owing to the unambiguous assignment, this publication concentrates on two parameters: (1) my resignation and (2) dismissal. The former is defined as voluntary unemployment and the latter as involuntary unemployment. ${ }^{4}$ The full-time employment is determined as the reference category. Thus, this work focuses on the effects of transition from full-time employment to (in)voluntary unemployment.

\footnotetext{
${ }^{3}$ It is argued that rise in job satisfaction is associated with a gain in life satisfaction.

${ }^{4}$ Of course there are some cases of doubt, e. g. when the employee forces the dismissal. This case is treated as an outlier in this work.
} 
Second, job prospects at the time of leaving a job could be relevant for life satisfaction. This can be addressed by the following question:

Did you have a new contract or a prospective job before you left your last position? [Yes, a prospective job; Yes, a new contract; No, I didn't have anything lined up; I didn't look for a new job]

Third, some additional answer options for the job leaving were analyzed with respect to their effect on life satisfaction: office/work is closed; mutual agreement; temporary job or apprenticeship had been completed; suspension; purpose of self-employment/business; transfer within the company by own wishes; transfer by company to another position.

Fourth, the regressors (1) office/work is closed, (2) mutual agreement, (3) temporary job or apprenticeship had been completed, and (4) purpose of self-employment/business were combined with the job prospects. ${ }^{5}$

To identify a potential causal effect of unemployment on life satisfaction, exogenous reasons for unemployment that are not connected with life satisfaction are essential. The closing of office/work can be treated as an exogenous reason for unemployment. Therefore, reverse causality can be precluded. ${ }^{6}$ This closing separates the working population in treatment and control group. In this case what can be assumed is that the treatment group does not systematically differ from the control group. Therefore, an average treatment effect (in contrast to an average treatment effect on the treated) can be supposed. $^{7}$

Life satisfaction is surveyed in the SOEP every year using the question "How satisfied are you with your life, all things considered?". Individuals rate their life on an 11-point scale (ranging from 0 "completely dissatisfied" to 10 "completely dissatisfied"). All in all this scale is considered to be reliable and valid (e. g. Schimmack, 2009).

To ensure unbiased estimates, some control variables were used in the regressions of this publication: family status ( $0=$ not married; divorced; separated from my spouse/partner; spouse/partner died; spouse live abroad; 1 =married, living together) and subjective current health (bad; poor; satisfactory; good; very good). In latter case, dummy-variables were created to maintain the ordinality of this variable. Furthermore, the logarithmized net household equivalent income and year effects were included in the regressions. A summary about the descriptive statistics of control variables and life satisfaction is illustrated by table 1 .

\footnotetext{
${ }^{5}$ This selection is primarily caused by contentual and sample size reasons.

${ }^{6}$ Analogous argumentations: For instance, Kassenboehmer and HaiskenDeNew (2009), Marcus (2012; 2013) or Schmitz (2011).

${ }^{7}$ But one point is important to keep in mind: these closings could depend on the sector. Therefore, anticipation effects cannot be excluded. Thus, this generalization should be treated carefully.
} 
Table 1: Descriptive Statistics of dependent variable and control variables $(\mathrm{n}=248.627)$

\begin{tabular}{l||rrrr} 
& Mean & SD & Min & \multicolumn{2}{c}{ Max } \\
\hline \hline life satisfaction & 6,98 & 1,78 & 0 & 10 \\
log net household equivalent income & 7,23 & 0,5 & 0 & 11,13 \\
subjective current health (1=bad) & 0,04 & 0,19 & 0 & 1 \\
subjective current health (1=poor) & 0,13 & 0,34 & 0 & 1 \\
subjective current health (1=satisfactory) & 0,32 & 0,47 & 0 & 1 \\
subjective current health (1=good) & 0,41 & 0,49 & 0 & 1 \\
subjective current health (1=very good) & 0,1 & 0,3 & 0 & 1 \\
married (1=yes) & 0,6 & 0,49 & 0 & 1
\end{tabular}

Moreover, table 2 gives an overview over the number of cases regarding the voluntary and involuntary unemployment plus job prospects.

Table 2: Number of cases: voluntariness and job prospects

\begin{tabular}{l||r} 
& $\mathbf{n}$ \\
\hline \hline leaving a job & 24.586 \\
\hline office/work is closed & 1.420 \\
my resignation & 4.650 \\
dismissal & 3.803 \\
mutual agreement & 1.591 \\
temporary job or apprenticeship had been completed & 3.280 \\
reaching retirement age/ pension & 1.481 \\
suspension & 1.145 \\
purpose of self-employment/business & 744 \\
\hline missing option & 8.241 \\
prospective job & 3.545 \\
new contract & 3.087 \\
absent job hunting & 4.711
\end{tabular}

\section{4) Econometric background}

By estimating satisfaction regressions, it is essential to control for unobserved heterogeneity (cf. Ferrer-i-Carbonell \& Fritjers, 2004). An intuitive way to do this is to use linear fixed-effectsregressions with cluster-robust standard errors (Stock \& Watson, 2008).

The following model is the starting point (for further details see: Bauer, Fertig \& Schmidt, 2009, p. 349-352):

$$
Y_{i t}=\beta_{0}+\beta_{1} X_{i t}+\underbrace{\alpha_{i}+\varepsilon_{i t}}_{v_{i t}}
$$

$\mathrm{i}=1, \ldots, \mathrm{N}$ : individuals in dataset

$\mathrm{t}=1, \ldots, \mathrm{T}$ : different time periods

$\beta_{0}=$ constant 
$\mathrm{X}_{\mathrm{it}}=$ time variant variables

$\alpha_{\mathrm{i}}=\mathrm{N}$ unknown constants that have to be estimated

$\varepsilon_{\mathrm{it}}=$ idiosyncratic error term

$v_{\mathrm{it}}=$ compound error term

It is necessary to keep in mind that one has to separate between $X_{i t}$ and $Z_{i}$ (not displayed). The latter are time invariant variables, for instance sex. In this work the dependent variable is life satisfaction.

The FE-estimator is unbiased in the presence of strict exogeneity. This estimator allows a correlation between the regressors and not observed attributes of the individuals, as long as they are time-invariant. Therefore, a correlation between $\alpha_{i}$ and $X_{i t}$ is allowed. Whereas the idiosyncratic error term must not correlate with $\mathrm{X}_{\mathrm{it}}$ (for further details: Wooldridge, 2002, p. 251-254).

The variation of variables in panel data (over time and individuals) makes it possible to eliminate $\alpha_{i}$ via a transformation of the displayed model: the so called "Fixed-Effects-Transformation". Based on equation (4-1) a mean over time is generated for all individuals $\mathrm{i}$ :

$$
\bar{Y}_{i}=\beta_{0}+\beta_{1} \bar{X}_{i}+\alpha_{i}+\bar{\varepsilon}_{i}
$$

With $\bar{Y}_{i}=T^{-1} \sum_{t=1}^{T} Y_{i t}$ and $\bar{X}_{i}=T^{-1} \sum_{t=1}^{T} X_{i t}$ for all $\mathrm{i}=1, \ldots$, N. By subtraction of equation (4-2) from equation (4-1), the result is:

$$
\begin{array}{r}
\tilde{Y}_{i}=\beta_{1} \tilde{X}_{i}+\tilde{\varepsilon}_{i} \\
\text { with } \tilde{Y}_{i}=Y_{i t}-\bar{Y}_{i}, \tilde{X}_{i}=X_{i t}-\bar{X}_{i} \text { and } \tilde{\varepsilon}_{i}=\varepsilon_{i t}-\bar{\varepsilon}_{i} .
\end{array}
$$

In equation (4-3) fixed effects $\alpha_{i}$ are eliminated. With this fixed-effects-transformation the researcher gets an unbiased estimator of the parameter $\beta_{1}$ when he uses the OLS-method. Therefore, a scientist could estimate the average effect of unemployment on life satisfaction with a FE-regression.

In addition, conditional fixed-effects logistic regression, probit-adapted OLS (POLS) with fixed effects and the Blow-Up and Cluster (BUC) estimator are used to check the robustness (see table 3 ). ${ }^{8}$

\section{5) Findings and discussion}

First, the general effect of unemployment is analyzed: The effect of job-leavings on life satisfaction is rather small $(\beta=-.122, p<.01$; men: $\beta=-.188, p<.01$; women: $\beta=-.058, p<.01)$. However, picture changes drastically when the backgrounds of the job-leavings are taken into account. Based on FE-regressions it can be demonstrated that voluntary unemployment does not change life satisfaction significantly. In contrast to this finding, involuntary unemployment reduces life satisfaction markedly $(\beta=-.486, p<.01)$. This applies for men and women.

\footnotetext{
${ }^{8}$ For technical details: CLFE (Kassenboehmer \& Haisken-DeNew, 2009), POLS (van Praag \& Ferrer-i-Carbonell, 2008) and BUC estimator (Baetschmann, Staub \& Winkelmann, 2011). Detailed regression results are available from the author on request.
} 
When the job prospects are considered as well, some clear evidences can be emphasized: If an individual is involuntarily unemployed and has nothing lined up to that point, life satisfaction drops down $(\beta=-.562, \mathrm{p}<.01)$. Furthermore, the combination of involuntary unemployment and absent job hunting noticeably reduces satisfaction $(\beta=-.369, \mathrm{p}<.01)$. Whereas the connection of involuntary unemployment and a prospective job does not change the satisfaction significantly. All those effects apply for men and women equally. On the $10 \%$-level the connection of involuntary unemployment and a new contract raises satisfaction $(\beta=.257)$, but only for women $(\beta=.546, p<.05)$. To recap, involuntary unemployment that is not accompanied by a prospective job or a new contract reduces satisfaction.

Likewise, the combination of a voluntary unemployment and a missing option decreases satisfaction $(\beta=-.309, \mathrm{p}<.01)$, although this effect is only significant for men $(\beta=-.457, \mathrm{p}<.01)$. In conjunction with a prospective job, the influence is insignificant. However, an association of a new contract and a voluntary unemployment slightly increases life satisfaction $(\beta=.135, \mathrm{p}<.01)$. In contrast to the combination of involuntary unemployment and absent job hunting, this perspective with a voluntary unemployment diminishes satisfaction significantly. This is even true for both sexes.

To summarize, a job prospection often does not change satisfaction significantly. Only if a new contract is signed the contentment goes up. This positive effect can be observed for men as well as women. A lack of job prospects while leaving a job reduces satisfaction.

The next passage considers more opportunities. Beginning with the highest negative influences on life satisfaction: The purpose of self-employment/business $(\beta=-.437, \mathrm{p}<.01)$, office/work is closed $(\beta=-.342, p<.01)$, temporary job or apprenticeship had been completed $(\beta=-.288, p<.01)$, mutual agreement $(\beta=-.111, \mathrm{p}<.05)$. A positive influence has the suspension $(\beta=.277, \mathrm{p}<.01)$ and possibly the transfer within the company by own wishes $(\beta=.296, \mathrm{p}<.10)$. However, the transfer by company to another position does not change satisfaction significantly.

Separated by sex, the following findings were made: The purpose of self-employment/business (men: $\beta=-.466, p<.01$; women: $\beta=-.375, p<.01)$ reduces satisfaction moderately in both cases. Meanwhile, a transfer within the company by own wishes increases men's satisfaction heavily $(\beta=.563, \mathrm{p}<.01)$. This regressor does not affect women's satisfaction significantly. Because of the small sample size these results need to be interpreted with caution. Besides, the suspension only increases women's satisfaction $(\beta=.340, \mathrm{p}<.01)$. Maybe this is caused by background factors of a suspension, e. g. pregnancy.

Next, the exogenous stimulus is presented at the sub-group level. If an office shuts down, especially men's satisfaction drops down (men: $\beta=-.420, p<.01$; women: $\beta=-.172, p<.05$ ). Similar effects can be observed by an ending of a temporary job or apprenticeship (men: $\beta=-.376, p<.01$; women: $\beta=-.178$, $\mathrm{p}<.01)$. 
A lack of job prospects in combination with the above-mentioned opportunities influences satisfaction moderately (office closed: $\beta=-.486$, mutual agreement: $\beta=-.365$, end of a temporary job or apprenticeship: $\beta=-.543$ ) or substantially (purpose of self-employment/business: $\beta=-.837$ ) on $1 \%$ significance level. This result is even true for both sexes, but with much stronger effects for men. To conclude, these findings corroborate the special meaning of employment for men.

Moreover, the combination of (1) a closing of an office and (2) a prospective job reduces life satisfaction overall, but especially for men. The results may be interpreted as follows: The mixture of lacking security that can be associated with a prospective job and the sudden entry into unemployment could compromise the financial security. This argumentation is supported by the fact that a combination of a closing of an office and a job contract does not affect contentment significantly. ${ }^{9}$

Furthermore, the interplay of an end of a temporary job or apprenticeship and a new contract only increases men's satisfaction $(\beta=.321, p<.05)$. This can be interpreted as evidence for the crucial role of a continuous employment for men.

Besides, it should be mentioned that the new contract in mixture with the other three variables does not affect satisfaction significantly. It can be assumed that a new contract at the time of the purpose of self-employment/business has a huge economic importance. Perhaps the positive effects of a new contract are overlaid by the strong negative effects of the purpose of self-employment/business. ${ }^{10}$

All the findings can be interpreted as robust, because BUC- and POLS-estimations (with fixed effects) and also CLFE-regressions confirm the results (for an overview: table 3 ).

\footnotetext{
${ }^{9}$ As a side note: By knowing the circumstances of the new position (e. g. distance to residence, income discrepancies or working conditions) new explanatory approaches could be generated.

${ }^{10}$ If the new contract is not combined with one of the reasons for job leaving, it affects satisfaction slightly positive $(\beta=.12, p<.01)$. Incidentally, a lack of job prospects (without a combination with one of the reasons for job leaving) decreases satisfaction noticeably $(\beta=-.478, p<.01)$.
} 
Table 3: Overview about the effects: role of voluntariness and job prospects (SOEP-data, 1998-2009, unweighted)

\begin{tabular}{|c|c|c|c|c|c|c|c|c|c|c|c|c|}
\hline & \multicolumn{4}{|c|}{ Overall } & \multicolumn{4}{|c|}{ Men } & \multicolumn{4}{|c|}{ Women } \\
\hline & FE & BUC & CLFE & POLS & FE & BUC & CLFE & POLS & $\mathrm{FE}$ & BUC & CLFE & POLS \\
\hline unemployment & $-* *$ & $-* *$ & $-* *$ & $-* *$ & $-* *$ & $-* *$ & $-* *$ & $-* *$ & $-* *$ & $-* *$ & $-*$ & $-*$ \\
\hline voluntary unemployment & + & + & $+^{+}$ & $+^{+}$ & + & + & + & + & + & + & + & + \\
\hline involuntary unemployment & $-* *$ & $-* *$ & -** & $-* *$ & $-* *$ & $-* *$ & $-* *$ & $-* *$ & $-* *$ & $-* *$ & $-* *$ & $-* *$ \\
\hline missing option & $-* *$ & $-* *$ & $-* *$ & $-* *$ & $-* *$ & $-* *$ & $-* *$ & $-* *$ & $-* *$ & $-* *$ & $-* *$ & $-* *$ \\
\hline prospective job & - & + & - & + & + & + & - & + & - & - & - & - \\
\hline new contract & $+* *$ & $+* *$ & $+* *$ & $+* *$ & $+*$ & $+*$ & $+* *$ & $+* *$ & $+* *$ & $+* *$ & $+* *$ & $+* *$ \\
\hline absent job hunting & - & - & - & - & $-*$ & $-*$ & $-^{+}$ & $-^{+}$ & + & + & $+^{+}$ & $+^{+}$ \\
\hline $\begin{array}{l}\text { involuntary unemployment and } \\
\text { missing option }\end{array}$ & $-* *$ & $-* *$ & $-* *$ & $-* *$ & $-* *$ & $-* *$ & $-* *$ & $-* *$ & $-* *$ & $-* *$ & $-* *$ & $-* *$ \\
\hline $\begin{array}{l}\text { involuntary unemployment and } \\
\text { prospective job }\end{array}$ & - & - & - & - & - & - & + & - & - & - & $-^{+}$ & - \\
\hline $\begin{array}{l}\text { involuntary unemployment and } \\
\text { new contract }\end{array}$ & $+^{+}$ & $+^{+}$ & + & + & + & + & - & - & $+*$ & $+*$ & + & $+*$ \\
\hline $\begin{array}{l}\text { involuntary unemployment and } \\
\text { absent job hunting }\end{array}$ & $-* *$ & $-* *$ & $-*$ & $-* *$ & $-*$ & $-*$ & - & $-*$ & $-*$ & $-*$ & $-^{+}$ & $-*$ \\
\hline $\begin{array}{l}\text { voluntary unemployment and } \\
\text { missing option }\end{array}$ & $-* *$ & $-* *$ & $-*$ & $-* *$ & $-* *$ & $-* *$ & $-* *$ & $-* *$ & - & - & - & - \\
\hline $\begin{array}{l}\text { voluntary unemployment and } \\
\text { prospective job }\end{array}$ & + & $+^{+}$ & + & + & $+^{+}$ & $+*$ & + & $+*$ & + & + & - & - \\
\hline $\begin{array}{l}\text { voluntary unemployment and } \\
\text { new contract }\end{array}$ & $+* *$ & $+* *$ & $+* *$ & $+* *$ & $+*$ & $+*$ & $+* *$ & $+*$ & $+*$ & $+* *$ & $+* *$ & $+*$ \\
\hline $\begin{array}{l}\text { voluntary unemployment and } \\
\text { absent job hunting }\end{array}$ & - & - & - & - & - & - & - & - & - & - & - & - \\
\hline office/work is closed & -** & -** & -*** & -*** & -** & -*** & -*** & -** & $-*$ & -* & $-*$ & $-^{+}$ \\
\hline mutual agreement & $-*$ & $-*$ & $-^{+}$ & $-^{+}$ & - & - & - & - & $-^{+}$ & - & - & - \\
\hline $\begin{array}{l}\text { temporary job or apprenticeship } \\
\text { had been completed }\end{array}$ & $-* *$ & $-* *$ & $-* *$ & $-* *$ & $-* *$ & $-* *$ & $-* *$ & -*** & $-* *$ & $-* *$ & $-^{+}$ & $-*$ \\
\hline suspension & $+* *$ & $+* *$ & $+* *$ & $+* *$ & + & + & - & + & $+* *$ & $+* *$ & $+* *$ & $+* *$ \\
\hline 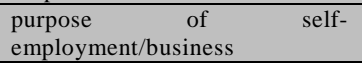 & $-* *$ & $-* *$ & $-* *$ & $-* *$ & $-* *$ & $-* *$ & $-* *$ & $-* *$ & $-* *$ & $-* *$ & $-*$ & $-* *$ \\
\hline $\begin{array}{l}\text { transfer within the company by } \\
\text { own wishes }\end{array}$ & $+^{+}$ & + & $+^{+}$ & + & $+* *$ & $+* *$ & $+* *$ & $+* *$ & - & - & - & - \\
\hline $\begin{array}{l}\text { transfer by company to another } \\
\text { position }\end{array}$ & + & + & + & + & + & + & + & + & -* $^{*}$ & $-*$ & - & -** \\
\hline $\begin{array}{l}\text { office/work is closed: missing } \\
\text { option }\end{array}$ & -** & $-* *$ & $-* *$ & $-* *$ & -** & $-* *$ & $-* *$ & $-* *$ & $-* *$ & $-* *$ & $-*$ & $-* *$ \\
\hline $\begin{array}{l}\text { mutual agreement: missing } \\
\text { option }\end{array}$ & -** & $-* *$ & -** & -** & -* & $-*$ & $-*$ & -* & -*** & $-* *$ & -** & -*** \\
\hline $\begin{array}{l}\text { temporary job or apprenticeship } \\
\text { had been completed: missing } \\
\text { option }\end{array}$ & -** & $-* *$ & $-* *$ & -** & -** & -** & -** & -** & -** & $-* *$ & -** & -** \\
\hline 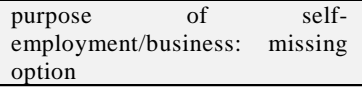 & -*** & -** & -*** & -** & -** & $-* *$ & $-* *$ & -*** & -*** & $-* *$ & -** & -*** \\
\hline $\begin{array}{lll}\text { office/work is closed: } \\
\text { prospective job }\end{array}$ & -* & -** & -*** & -** & -** & -** & -** & -** & - & - & $-^{+}$ & - \\
\hline $\begin{array}{l}\text { mutual agreement: prospective } \\
\text { job }\end{array}$ & - & - & - & - & + & - & - & + & - & - & - & - \\
\hline $\begin{array}{l}\text { temporary job or apprenticeship } \\
\text { had been completed: } \\
\text { prospective job }\end{array}$ & + & + & + & + & - & - & - & - & $+^{+}$ & + & $+^{+}$ & $+^{+}$ \\
\hline $\begin{array}{l}\text { purpose of } \\
\text { employment/business: } \\
\text { prospective job }\end{array}$ & - & - & - & - & - & - & - & - & - & - & - & - \\
\hline $\begin{array}{l}\text { office/work is closed: new } \\
\text { contract }\end{array}$ & + & + & + & + & $+^{+}$ & + & + & + & - & - & + & - \\
\hline mutual agreement: new contract & + & + & + & + & - & - & - & - & $+^{+}$ & $+^{+}$ & + & $t^{+}$ \\
\hline $\begin{array}{l}\text { temporary job or apprenticeship } \\
\text { had been completed: new } \\
\text { contract }\end{array}$ & $+*$ & $+^{+}$ & $+* *$ & $+*$ & $+*$ & $+*$ & $+* *$ & $+*$ & + & + & + & + \\
\hline $\begin{array}{ll}\text { purpose of } & \text { self- } \\
\text { employment/business: } & \text { new } \\
\text { contract } & \\
\end{array}$ & - & - & - & - & - & - & - & - & - & - & - & - \\
\hline $\begin{array}{l}\text { office/work is closed: absent } \\
\text { job hunting }\end{array}$ & + & + & - & + & - & - & - & - & $+*$ & $+* *$ & + & $+^{+}$ \\
\hline $\begin{array}{l}\text { mutual agreement: absent job } \\
\text { hunting }\end{array}$ & - & + & + & + & + & + & + & + & - & - & + & - \\
\hline $\begin{array}{l}\text { temporary job or apprenticeship } \\
\text { had been completed: absent job } \\
\text { hunting }\end{array}$ & - & - & - & - & $-^{+}$ & - & -* & - & + & + & + & + \\
\hline $\begin{array}{lr}\text { purpose } & \text { of } \\
\text { employment/business: } & \begin{array}{r}\text { self- } \\
\text { absent }\end{array} \\
\text { job hunting } & \end{array}$ & - & - & - & - & + & + & + & + & - & - & - & - \\
\hline
\end{tabular}

Comments: The signs (-/+) of beta-coefficients from FE-, BUC-, CLFE- and POLS-regressions are displayed. ${ }^{* *} \mathrm{p}<0.01$,

$* p<0.05,+p<0.1$. 


\section{6) Conclusion}

This publication investigates the relation between life satisfaction and unemployment by using SOEP data from 1998-2009. Two questions were raised:

- In which way affects the voluntariness of unemployment life satisfaction?

- What influences have job prospects after job termination on life satisfaction?

The findings can be summarized as follows:

(1) Compared with voluntary job leavings involuntary job leavings reduce life satisfaction remarkably. Based on these results, it can be assumed that the involuntary job leaving is a dramatic constraint in somebody's life that is associated with an exclusion of a major part of life, especially for men. ${ }^{11}$

(2) Besides, an absence of job prospects before leaving the former position reduces life satisfaction, too. It is assumed that this aspect underpins the meaning of employment and the significance freedom of choice has in the labour market.

(3) Moreover, a plant shutdown, an exogenous stimulus, decreases satisfaction. This is particularly true for men. Therefore, a contribution to the causality is made.

The findings suggest that classical political measures which go along with neoclassical theory of labor supply should be seen in a different light. Reduction of unemployment benefit or decreasing personal income tax would be good examples for these measures. It is much to be hoped that these findings could stimulate the public and especially the political debate on unemployment. Approaches for solutions could be further educations or intensified retraining measures to ease the reintegration into labour market.

This research questions should be addressed with a similar empirical approach in other panels, for instance the KLIPS (Korean Labor \& Income Panel Study). It needs to be considered that in SouthKorea men are often seen as bread-earners (Rudolf \& Kang, 2011). Therefore, there will probably occur noticeable differences between men and women. Moreover, in KLIPS questionnaire participants answer the question directly, whether they leave the job voluntarily or involuntarily. Beyond that, people were asked meticulously regarding the specific reason for leaving the job $[22$ options from childbirth/childcare to undesirable work hours or working conditions]. This fastidious query of reasons could be a model for other household panels, too.

Future research might attempt to define voluntariness of unemployment in an alternative way. Powdthavee (2012) demonstrated with BHPS-data that dissatisfaction with financial situation and the job in the year before unemployment occurred. Hence, not all job losses are exogenous. Consequently, unemployment can be seen as voluntary when a substantial reduction in working satisfaction emerged

\footnotetext{
${ }^{11}$ In the next decades, these gender discrepancies could be even smaller, especially against the background of the ongoing increase in job significance for women in Germany.
} 
in the year of unemployment or in the years before. This assumption is really strong, nevertheless it can be discussed.

To conclude, not just the actual conditions, in this case employment status, are relevant. Even the capabilities, here freedom of choice to work, should be taken into account. To go one step further: If unemployment is treated as poverty in the economic field or exclusion of one major area of life, the capability approach could be used as an appropriate tool to measure poverty. This has one simple reason: The capability approach separates between conditions and capabilities (for further details in this context: Hajek, 2013). 


\section{References}

Baetschmann, G., Staub, K. E \& Winkelmann, R. (2011). Consistent Estimation of the Fixed Effects Ordered Logit Model (IZA Discussion Paper No. 5443). Bonn: Institute for the Study of Labor.

Bauer, T. K., Fertig, M. \& Schmidt, C. M. (2009). Empirische Wirtschaftsforschung. Berlin: Springer.

Chamberlain, G. (1980). Analysis of covariance with qualitative data. Review of Economic Studies, 47 (1), 225-238.

Clark, A. E. \& Georgellis, Y. (2012). Back to Baseline in Britain: Adaptation in the BHPS (IZA Discussion Papers No. 6426). Bonn: Institute for the Study of Labor.

Diener, E. \& Seligman, M. (2004). Beyond money: toward an economy of well-being. Psychological Science in the Public Interest, 5 (1), 1-31.

Diener, E., Suh, E. M., Lucas, R. E. \& Smith, H. L. (1999). Subjective well-being: Three decades of progress. Psychological Bulletin, 125 (2), 276-302.

Ferrer-i-Carbonell, A. \& Frijters, P. (2004). How important is methodology for the estimates of the determinants of happiness? Economic Journal, 114 (497), 641-659.

Hajek, A. (2013). Der Einfluss von Armut und Reichtum auf die Lebenszufriedenheit. Eine empirische Analyse mit dem SOEP unter besonderer Berücksichtigung des Capability Approach. München: Herbert Utz Verlag.

Kassenboehmer, S. C. \& Haisken-DeNew, J. (2009). You're Fired! The Causal Negative Effect of Unemployment on Life Satisfaction. Economic Journal. 119 (536), 448-462.

Luhmann, M. \& Eid, M. (2009). Does It Really Feel the Same? Changes in Life Satisfaction Following Repeated Life Events. Journal of Personality and Social Psychology, 97 (2), 363-381.

Marcus, J. (2012). Does job loss make you smoke and gain weight? (SOEPpapers 432). DIW: Berlin.

Marcus, J. (2013). The effect of unemployment on the mental health of spouses - Evidence from plant closures in Germany (SOEPpapers 488). DIW: Berlin.

Pavot, W., \& Diener, E. (2008). The Satisfaction With Life Scale and the emerging construct of life satisfaction. Journal of Positive Psychology, 3 (2), 137-152.

Powdthavee, N. (2012). Jobless, friendless, and broke: What happens to different areas of life before and after unemployment? Economica, 79 (315), 557-575.

Rudolf, R. \& Kang, S.-J. (2011). The Baseline Hypothesis Revisited. Evidence from a NeoConfucianist Society. University of Göttingen.

Schimmack, U. (2009). Well-being: Measuring wellbeing in the SOEP. Schmollers Jahrbuch Zeitschrift für Wirtschafts- und Sozialwissenschaften, 129 (3), 1-9. 
Schmitz, H. (2011). Why are the unemployed in worse health? The causal effect of unemployment on health. Labour Economics, 18 (1), 71-78.

Stock, J. H. \& Watson, M. (2008). Heteroskedasticity-Robust Standard Errors for Fixed Effects Panel Data Regression. Econometrica, 76 (1), 155-174.

Sumner, L. W. (1996). Welfare, happiness, and ethics. Oxford: Claredon Press.

van Praag, B. M. S. \& Ferrer-i-Carbonell, A. (2008). Happiness Quantified: A Satisfaction Calculus Approach. Revised Edition. Oxford: Oxford University Press.

Wagner, G. G., Frick, J. R. \& Schupp, J. (2007). The German Socio-Economic Panel Study (SOEP) Scope, Evolution and Enhancements. Schmollers Jahrbuch, 127 (1), 139-169. http://schmollersjahrbuch.diw.de/schmollersjahrbuch/webcontent/2007/Wagner\%20et\%20al.pdf

Winkelmann, L. \& Winkelmann, R. (1995) Unemployment: where does it hurt (Centre for Economic Policy Research Discussion Paper 1093)? London: Centre for Economic Policy Research.

Winkelmann, L. \& Winkelmann, R. (1998). Why are the unemployed so unhappy? Evidence from panel data. Economica, 65 (257), 1-15.

Wooldridge, J. M. (2002). Econometric Analysis of Cross Section and Panel Data. Cambridge, MA: MIT Press. 